\title{
Immersing into the Past: An Augmented Reality Method to Link Tangible and Intangible Heritage Dragoș GHEORGHIU, Livia ȘTEFAN
}

\begin{abstract}
The current IT and digital technologies such as Mobile Augmented Reality (MAR) enable the overlap of digital and real world information in relation with a topic, in an engaging and efficient manner, and therefore can be used to store intangible heritage and to study it in the context as well. The current paper refers to such an augmentation of cultural information, performed at the Kallatis site, whose ruins, at present mostly covered by the modern town, do not offer sufficient information on the complexity of the Greek civilization. The implementation of a MAR application consisted in defining several points of interest of the important local archaeologic discoveries, which can trigger, for the visitors using our application, an augmentation of the historical site with images and videos. With the current research work, the authors propose and demonstrate that a mobile MAR application can constitute a modern method for providing visitors with an immersive and holistic experience for understanding the local material and intangible heritage.
\end{abstract}

Keywords: Intangible Heritage, Mobile Augmented Reality, Immersion, Points of Interest, Re-enactment.

\section{Introduction}

Currently, the heritage is not addressed as an undivided whole, but rather segregated into two categories: material heritage and intangible heritage. A holistic approach to heritage should address both aspects, i.e. the material and the immaterial, whenever the available data allow for it. From an educational perspective, both heritage categories should be presented in their original, organic connection, in order to deliver as explicit as possible image of the culture of past societies to the public.

This endeavour is possible with current IT and digital technologies such as Mobile Augmented Reality (MAR), which make possible the overlap of digital and real world information, by taking advantage of the technical capabilities of smartphones and tablets (e.g. mobile communication, GPS receiver, gyroscope or front camera).

The use of MAR allows for the display of information in relation with a topic in an engaging and efficient manner. During the last few years, the authors have experimented with the MAR method in order to augment the archaeological information of some heritage sites (Gheorghiu and Ștefan 2014a; 2014b; 
2019) and have documented their experience with both material and intangible heritage in the present paper.

In the case of heritage sites, the MAR technology can enhance the information corresponding to a defined Point of Interest (POI) by superposing the intangible heritage (e.g. the specific technologies of a site) on the architectural remains of that site.

This palimpsest of information representing an augmentation of existing data produces an immersive mood similar to the one experienced when exploring art works or virtual worlds. The immersion is generated by the rich information placing the user at the centre of a new reality. In the case of MAR, the newly created reality is a combination of real and digital content.

In the current paper the authors provide details on the design and implementation of a MAR application and discuss how this can constitute a modern method for providing visitors with an immersive and holistic experience for understanding the local heritage, and thus for preserving it. How such MAR applications can be rendered more accessible to broader public is also discussed.

\section{Augmenting reality}

The attempt to recover the Past as truthfully as possible is enabled by current IT and digital technologies such as mobile devices and Augmented Reality technology (AR).

The AR technology, systems and applications were first explained by Azuma (1997), Azuma et al. (2001), and recently surveyed by Carmigniani and Furht (2010) or Carmigniani et al. (2011), among others. Alkhamisi and Monowar (2013: 25) citing Yang (2011) mention other similar technologies among the benefits of AR, such as Virtual Reality, as "having a better sense and interaction of reality whereas it lays emphasis on the organic integration of virtual environment and the real world".

The mobility of smartphones and tablets allows their utilization in a context, while AR allows the overlay of digital content over the visible real information to be accomplished in situ, which makes the user undergo an important emotional and cognitive experience.

Chi-Yin Yuen et al. (2011: 135) analyses several milestones and innovations in including AR in the educational projects and offers an optimistic perspective on the evolution of the AR when he states "through the continuing research in AR technologies, it is possible that AR will eventually lead to a complete and immersive VR (Virtual Reality), allowing humans to surround themselves with a convincing virtual environment in which they can interact with other humans, with computers, and with programs." 


\subsection{MAR, a special case of $A R$}

Mobile Augmented Reality (MAR) makes available the AR technology for the mobile devices (smartphones and tablets), making it a technology publicly available to any user. MAR makes the overlap of digital content on the real world view possible, even on smaller screens, by using key mobile affordances: data communication (mobile and wireless networks), location sensing (GPS), user direction (gyroscope), front video camera, and performant displays.

A category of MAR is based on the location sensing technologies, by defining location-aware augmentations.

By making advanced use of mobile technologies, it is possible to create socalled "pervasive applications" or "ubiquitous applications", i.e. applications which can be used in any place, can interact with objects and places, and are usually employed in outdoor environments. Moreover, by defining characteristics of the pervasive applications in the context of more complex usage such as location-based games, Thomas (2006) asserts that these can also be used at any time, the content or actions being activated by the user's location.

\subsection{MAR and intangible heritage}

The potential of digital information recommends the use of MAR in the case of intangible heritage, to highlight, discover and educate. The augmentation of material data such as architectural structures, with immaterial data, such as technologies, provides a comprehensive image of the daily life in the Past. We believe that ancient technologies are an important aspect of the intangible heritage, and that they should be reproduced by experiment and transferred into the AR technology, thus being secured and transformed into didactic material.

From this perspective, the MAR application is also an educational affordance, with important benefits in the case of intangible heritage, as "pervasive learning is not a form of delivered instruction, it is a social process that happens at a time and place of the learners' choosing instead [...], supports spontaneous, unscripted learning." (Heljakka and Ihamäki 2018: 81).

In the case of heritage sites, MAR technologies provide the user with a different kind of information related to the site, overlapped on Points of Interest (POI). This palimpsest of information, which represents an augmentation of existing data, produces an immersive mood similar to the one experienced when exploring art works, or virtual worlds.

Similar to a book reader, who identifies himself with a character, the user of the MAR application will psychologically immerse in the presented digital content. The immersion is generated by the rich information which places the user at the centre of a new reality. In the case of MAR, the newly created reality is a combination of real and digital content. 


\section{Similar research}

MAR applications for heritage, cultural tourism and education benefit from a significant amount of research work, essentially for bringing virtual reconstruction of historical sites to the public.

Abowd et al. (1997) were the first to research and develop an experimental context-aware mobile Cyberguide to provide user services.

The first relevant MAR application in archaeology was "Archeoguide", an AR guide for archaeological sites (Vlahakis et al., 2002: 52) which offered, on custom manufactured mobile devices, personalized visitor tours of Greek archaeological sites. The augmentations were presented as historical information, reconstructed sites and simulations of ancient life.

Noh et al. (2009: 50) also explores the educational potential of both Virtual Heritage and digital culture heritage "to preserve, protect and interpret [...] culture and history."

In Gheorghiu and Ștefan (2014b) the topics of immaterial heritage and digital memory are discussed, while in Ștefan and Gheorghiu (2015) and Gheorghiu and Ștefan (2019) MAR usage for revealing "invisible" communities is explored.

Norsyafawati et al. (2016: 491) performs an exploratory literature review of MAR applications dealing with cultural heritage content. The authors extrapolate the MAR augmentations as "any graphic visual representations of information, data or knowledge intended to present complex information quickly and clearly" that is also able to improve user understanding of visual patterns. Similarly, in Gheorghiu and Ștefan (2014a; 2018), MAR augmentations of the archaeological record are developed as a sequence of different types of media and information, in a structure that mimics the fractals.

Tenedório and Marques (2017) address the built heritage and discuss how can 3D models and augmented reality visualization, based on mobile platforms, enhance the value of urban heritage. The authors are considering the built heritage not only part of the urban public space, but also "a space of memory" (Tenedório and Marques 2017: 4). MAR applications "can be understood as the dematerialized extension of the public space with patrimonial value.” (Tenedório and Marques 2017: 5).

Zaibon et al. (2015: 235) investigate the applicability of Mobile Augmented Reality in Malaysian cultural heritage sites, by means of a user study that revealed that $90 \%$ of the respondents consider that mobile AR has a potential to be used at the cultural heritage sites. 


\section{Augmenting the archaeologic reality. A case study}

The benefits of using AR technology as part of the process of heritage preservation are vast, as it allows for the display of information in relation with an object or place, in an engaging and efficient manner.

As a case study, the authors selected an archaeologic site, iconic for the Hellenistic period, i.e. the Greek city of Kallatis. Currently, the remains of the city are mostly covered by the modern town, i.e. Mangalia (Figure 1).

The implementation of the MAR application consists in defining several POIs of the important local archaeologic discoveries, which can trigger the visitors using our application, an augmentation of the historical site with images and videos of re-enactments (Figure 2).

The augmentation of the tangible heritage with the intangible one is achieved with video films representing re-enactments of daily life scenes. With these kind of augmentations, i.e. videos, the newly created reality is a combination of real information and immersive digital content. The visitor can switch from real to virtual, and vice versa. This user experience will create an augmented and immersive illusion of being in this "new reality".

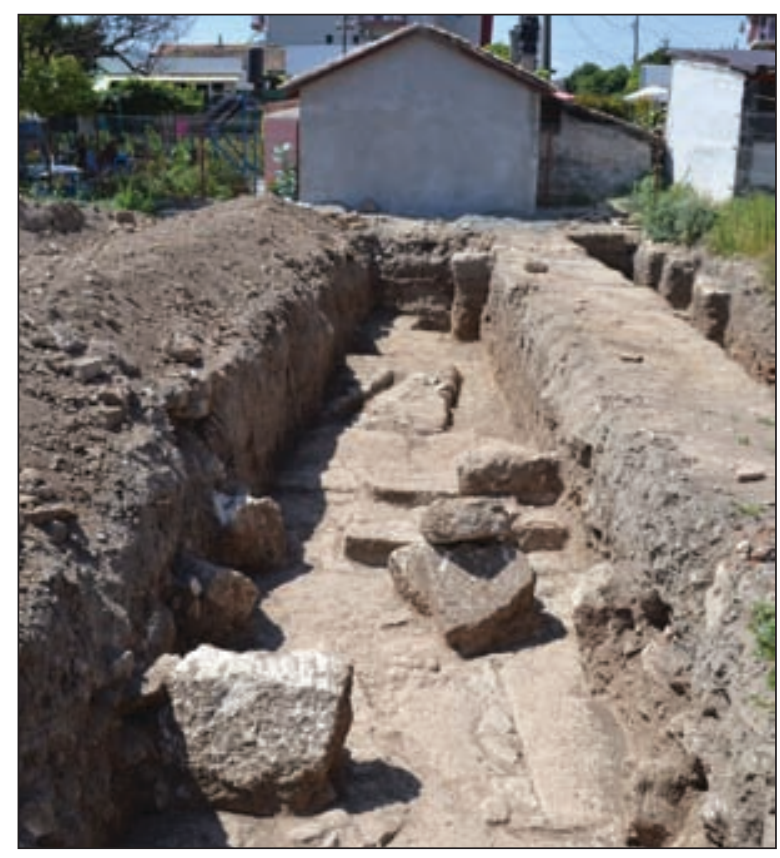

Figure 1. Excavations showing the ancient Greek town Kallatis overlapped by the modern town of Mangalia, 2016 (photo D. Gheorghiu)

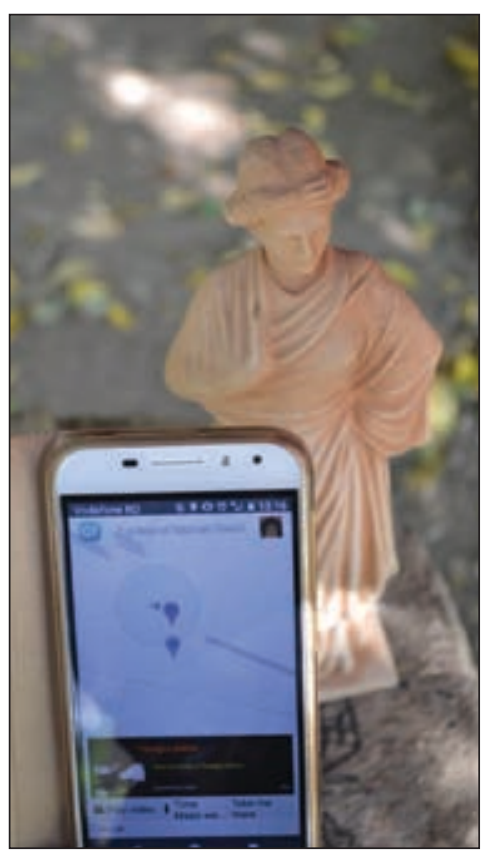

Figure 2. POls of the important local archaeological discoveries (photo D. Gheorghiu) 
Figure 3. A theatrical scene with characters dressed in Greek costumes, reproduced after the Tanagra costumes (photo D. Gheorghiu)

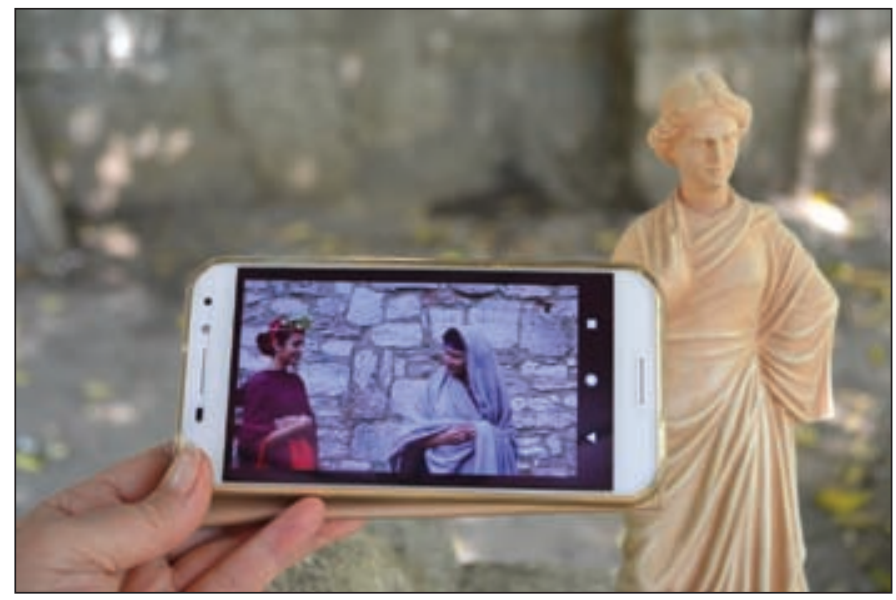

In one example, represented by the Kallatis site where Tanagra figurines have been discovered, the visitors can watch both theatrical scenes with characters dressed in ancient costumes, reproduced after the figurines' costumes, and the modelling of such statuettes (Figure 3).

\section{The kallatis $A R$ application}

kallatisAR is a MAR application developed on the Layar commercial AR platform (Layar 2018).

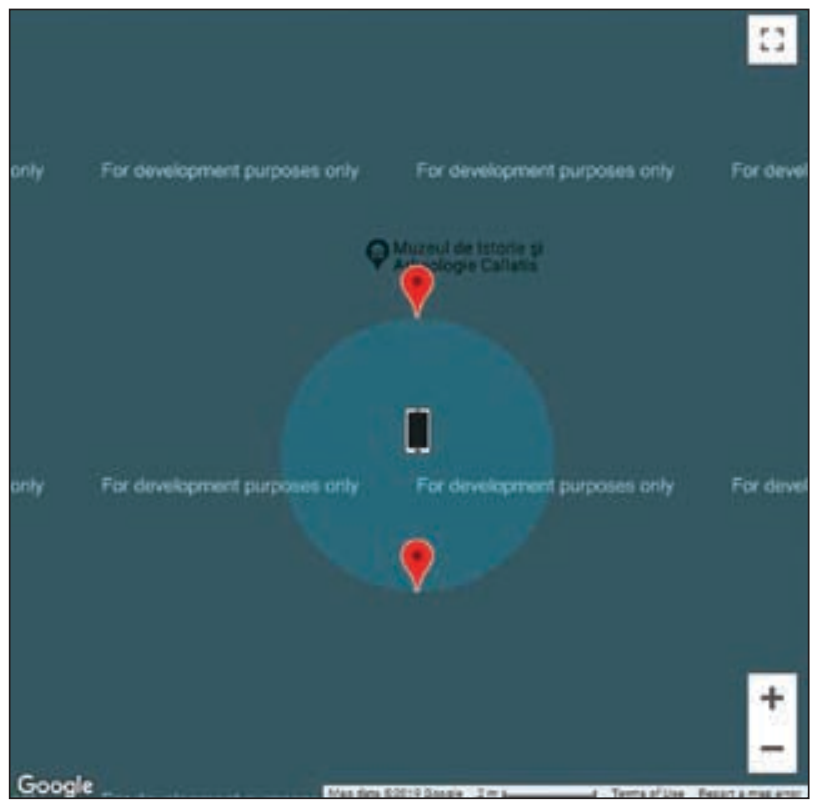

Figure 4. POls on the map view of kallatis $A R$ application
The application covers a geographical area by means of defined POIs, augmented with texts and videos representing re-enactments.

The augmentations are triggered by the user's location, i.e. when approaching within a $5 \mathrm{~m}$ radius around each POI (Figure 4).

In order to access the application, users need to install the Layar AR platform on their mobile phones or tablets and to 
search for the kallatisAR layer in the Geo category. (Figure 5)

\subsection{The User's expe-} rience with the kallatisAR application

The user interaction with the POIs was employed to deliver the content and also to provide an immersive experience on the material heritage linked to the immaterial heritage.

The POIs are defined within the archaeological site, in the real landscape.

The Layar platform offers pre-defined interface graphic elements (POI icons, billboards, message boards) which can be customized in terms of colours or fonts.

When the kallatisAR is launched, the user can "activate" a POI by either selecting it from the map view or by entering into the POI's range, in the AR view.

This action could be followed by the display of a 3D architectural reconstruction overlapped on the present architectural ruins, i.e. the material heritage.

By clicking the reconstruction in a defined

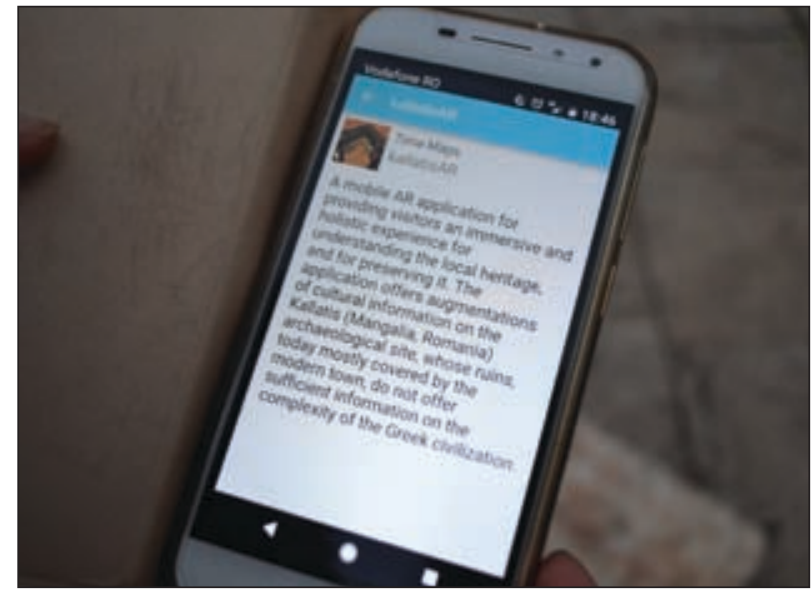

Figure 5. The Layar AR platform on a mobile phone with the kallatisAR layer in the Geo category (Photo D. Gheorghiu)

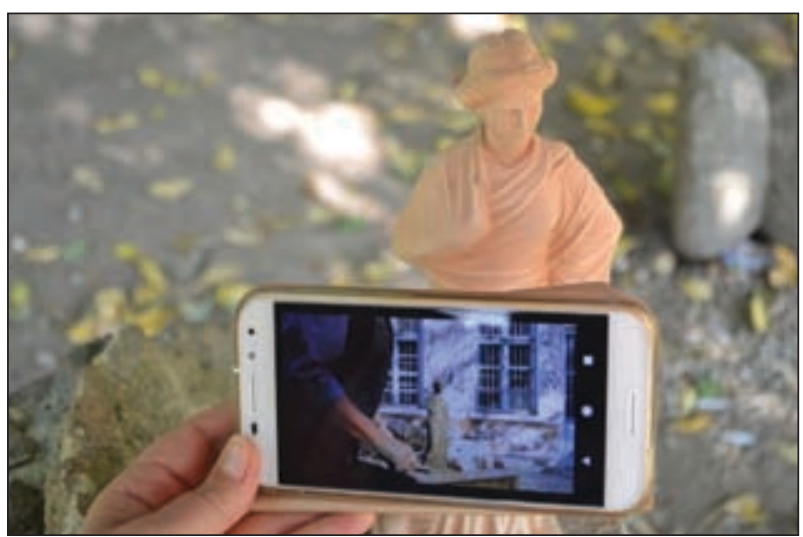

Figure 6. Video showing the modelling techniques of the Tanagra figurines (Photo D. Gheorghiu)

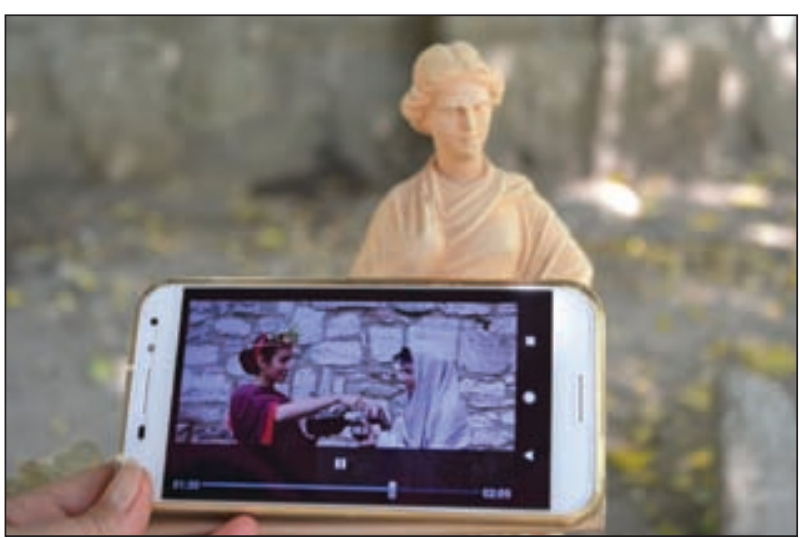

Figure 7. A re-enactment with characters dressed in Greek costumes (Photo D. Gheorghiu) 
sensitive area comprising a representative object, in the current case a Tanagra figurine, the re-enactment videos i.e. the intangible-immaterial heritage will be displayed, showing the modelling techniques of the figurines (Figure 6) and also a re-enactment with characters dressed in ancient costumes similar to those of the figurines (Figure 7).

\section{Visibility to the broader public}

To improve the visibility of the MAR applications to the broader public different media and methods were used by the authors:

- Time Maps website (www.timemaps.net);

- Social media, e.g. Facebook and Twitter;

\section{GEO LAYER KALLATISAR}

Figure 8. kallatisAR web page on the Layar site (top); kallatisAR tags and category on the Layar site (bottom)
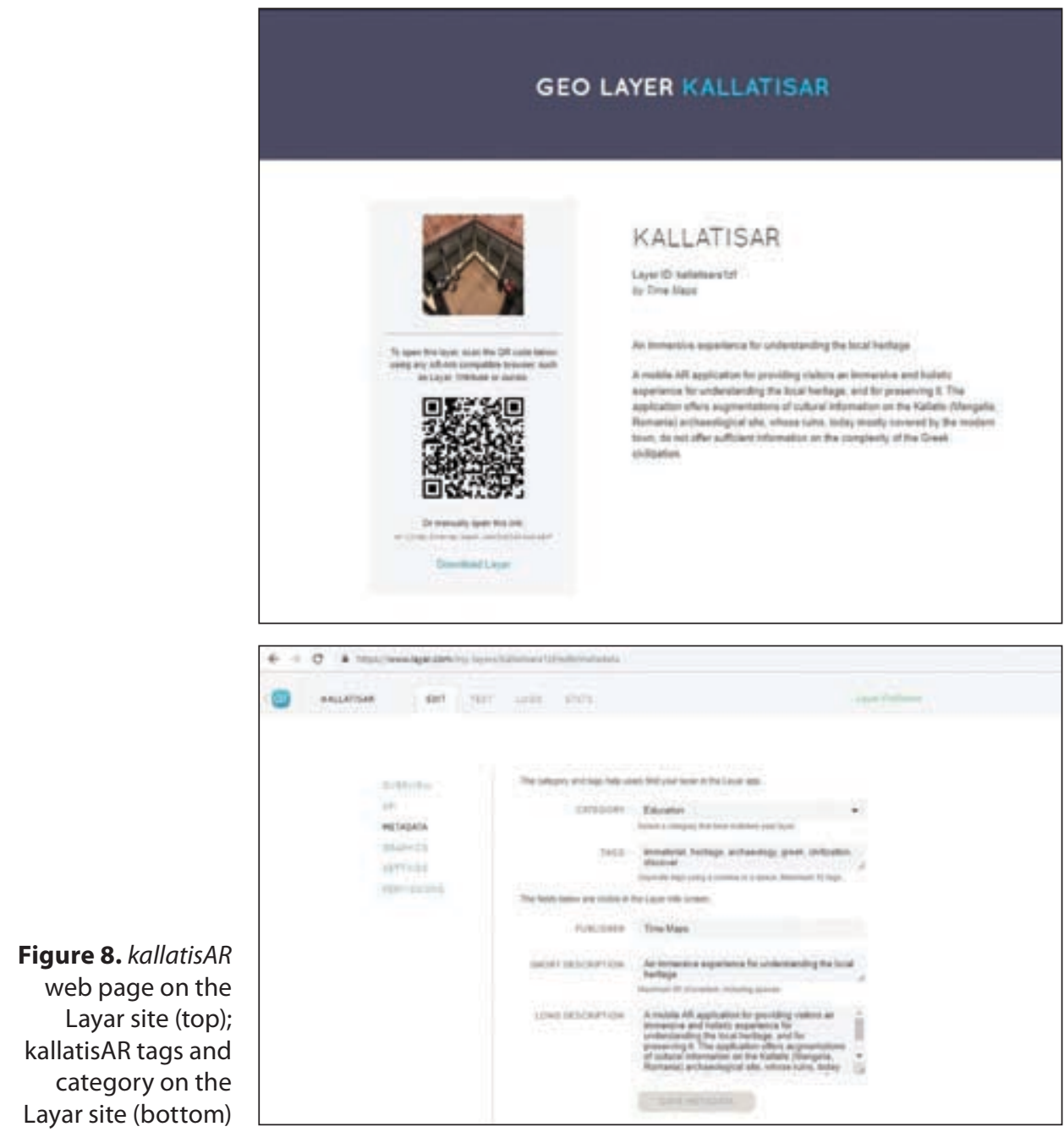
- in-situ posters, on the availability of the MAR application and how it can be accessed on mobile devices;

- $\mathrm{QR}$ codes for rapid access to the application.

Currently, from the kallatisAR application the users can access the Time Maps project, take a photo of the AR representation of the place, or share the information on social media sites.

On the Layar platform, finding the kallatisAR application by users and developers is facilitated by the Layar public application catalogue website (Figure 8).

Furthermore, to distinguish it and help users in selecting the kallatisAR from among other Layar applications, "immaterial, heritage, archaeology, Greek, civilization, discover" tags and "Education” category were defined.

\section{Conclusion}

The authors consider that a mobile MAR application represents a modern method for providing visitors an immersive and holistic experience for understanding the local heritage, and for preserving it.

MAR could offer the visitor an augmented immersion, and an experience of the Past much deeper than the one offered by conventional museums.

In concluding this paper, one can assume that ancient technologies are an important cultural feature that can assemble the material and the intangible heritage by the use of MAR. The Time Maps project where the authors experimented this synthesis, demonstrates the importance of the recovery of the ancient technologies for the revitalization of the contemporary folk traditions in different European locations. MAR can present technologies as augmentations of the current reality, like the re-enactments with characters dressed in ancient costumes who construct objects and display their daily use. In this case, an augmentation of the information of the historical context could have a strong immersive character, and can act as an efficient didactic method of understanding, teaching and transferring the past into the future.

\section{Acknowledgements}

The present research was carried within the PN II exploratory grant Time Maps. Real Communities, Virtual Worlds, Experimented Pasts. The authors thank Professor Sergiu Musteață for the kind invitation to contribute to this volume and the team of experimentalists and the team of actors that took part in the experiments in Vădastra village between 2011 and 2016. Many thanks to M. Bogdan Căpruciu for the useful remarks. 


\section{References}

Abowd, Gregory, Christopher G. Atkeson, Jason Hong, Sue Long, Rob Kooper, and Michael David Pinkerton. „Cyberguide: A mobile context-aware tour guide”. Wireless Networks 3, no. 5. (1997): 421-433.

Alkhamisi Abrar Omar and Muhammad M. Monowar. "Rise of Augmented Reality: Current and Future Application Areas", International Journal of Internet and Distributed Systems. (2013). 1 no. 4, (2013): 25-34. doi: 10.4236/ijids.2013.14005.

Azuma, Ronald. "A Survey of Augmented Reality", Presence: Teleoperators \& Virtual Environments, 6, no. 4 (1997): 355-385.

Azuma, Ronald, Yohan Baillot, Reinhold Behringer, Steven Feiner, Simon Julier, and Blair MacIntyre. "Recent Advances in Augmented Reality", IEEE Computer Graphics and Applications, 21, no. 6 (Nov./Dec. 2001): 34-47.

Carmigniani, Julie, and Borko Furht. "Augmented Reality: An Overview" In Hand book of Augmented Reality, edited by Julie Carmigniani and Borko Furht, 3-46. New York: Springer, 2010, http://dx.doi.org/10.1007/978-1-4614-0064-6_1

Carmigniani, Julie, Borko Furht, Marco Anisetti, Paolo Ceravolo, Ernesto Damiani, and Misa Ivkovic. "Augmented Reality Technologies, Systems and Applications," Multimedia Tools and Applications 51, no. 1 (2011): 341-377, http://dx.doi. org/10.1007/s11042-010-0660-6

Chi-Yin Yuen, Steve, Gallayanee Yaoyuneyong, and Erik Johnson. "Augmented Reality: An Overview and Five Directions in Education," Journal of Educational Technology Development and Exchange (JETDE) 4, no. 1 (2011): 119-140.

Fritz, F., A. Susperregui, and Maria Teresa Linaza (2005). Enhancing Cultural Tourism experiences with Augmented Reality Technologies. In: M. Mudge, N. Ryan and R. Scopigno (eds), The 6th International Symposium on Virtual Reality, Archaeology and Cultural Heritage VAST.

Gheorghiu, Dragoș, and Livia Ștefan. "Augmenting the Archaeological Record with ARt (The Time Maps Project)", In Augmented Reality Art: From an Emerging Technology to a Novel Creative Medium, edited by Vladimir Geroimenko, 255-276. Springer, 2014a.

Gheorghiu, Dragoș, and Livia Ștefan. "Patrimoniu imaterial şi memorie digitală: recuperarea, stocarea şi transmiterea tehnologiilor din trecut." In Arheologia şi politicile de protejare a patrimoniului cultural în România. Culegere de studii, Chişinău/ Iaşi, edited by Sergiu Musteaţă, 141-149. Chişinău: Editura ARC, 2014b.

Gheorghiu, Dragoș, and Livia Ștefan. "A Fractal Augmentation of the Archaeological Record: The Time Maps Project." In Augmented Reality Art, From an Emerging Technology to a Novel Creative Medium, Edition: 2, edited by Vladimir Geroimenko, 297-316. Springer International Publishing, 2018.

Gheorghiu, Dragoș, and Livia Ștefan. "Invisible Settlements: Discovering and Reconstructing the Ancient Built Spaces through Gaming." In: V. Geroimenko (ed.), Augmented Reality Games II, 83-102. Springer Nature, 2019. 
Heljakka, Katriina, and Pirita Ihamäki. "Designing a Pervasive Adventure Gamescape: Avoiding the Pitfalls in Creating Augmented LBGs for Playful Learning", Journal of Digital Media and Interaction 1, no. 2 (2018): 75-94.

Kounavis, Chris D., Anna E. Kasimati and Efpraxia D. Zamani. "Enhancing the Tourism Experience through Mobile Augmented Reality: Challenges and Prospects”, International Journal of Engineering Business Management 4, Special Issue Digital and Mobile Economy (2012): 1-6.

Layar web site. https://www.layar.com/, Accessed December 2018.

Marques, Luis, José António Tenedório, Malcolm Burns, Teresa Romão, Fernando Birra, João Marques, and Antero Pires. "Cultural Heritage 3D Modelling and visualisation within an Augmented Reality Environment, based on Geographic Information Technologies and mobile platforms". Architecture, City and Environment 11 no. 33. (2017): 117-136. 10.5821/ace.11.33.4686.

Mourkoussis, N., F. Liarokapis, J. Darcy, M. Pettetsson, P. Petridis, P.F. Lister, M. White. "Virtual and Augmented Reality Applied to Educational and Cultural Heritage Domains”.. In Proceedings of Business information Systems 2002, 367-373. Poznan, Poland, 2002.

Noh, Zakiah Mohd Shahrizal Sunar, and Zhigeng Pan. „A Review on Augmented Reality for Virtual Heritage System.” In Learning by Playing. Game-based Education System Design and Development. Edutainment. Lecture Notes in Computer Science, vol. 5670, edited by Maiga Chang, Rita Kuo, Kinshuk Gwo-Dong Chen, and Michitaka Hirose, 50-61. Berlin, Heidelberg: Springer, 2009.

Norsyafawati, Fatin, Nik Zulkarnaen Khidzir, Ahmad Rasdan Ismail and Khairul Azhar Mat Daud. "An Exploratory Study on Mobile Augmented Reality (AR) Application for Heritage Content”, Journal of Advanced Management Science 4, no. 6 (2016): 489-493. 10.12720/joams.4.6.489-493.

Pendit, Ulka Chandini, Syamsul Bahrin Zaibon, and Juliana A. Abubakar. "Digital Interpretive Media Usage in Cultural Heritage Sites at Yogyakarta”. Jurnal Teknologi (Sciences \& Engineering) 75, no. 4. (2015): 71-77. 10.11113/jt.v75.5069.

Ştefan, Livia, and Dragoș Gheorghiu. "E-Cultural Tourism for Highlighting the "Invisible" Communities_Elaboration of Cultural Routes Using Augmented Reality for Mobile Devices (MAR)." In Current Trends in Archaeological Heritage Preservation: National and International Perspectives, Proceedings of The International Conference, Iaşi, Romania, 2013, edited by Sergiu Musteață and Ştefan Caliniuc, 63-66. British Archaeological Reports International Series 2741, ISBN: 9781407314006, Oxford: Archaeopress, 2015.

Thomas, Siobhán. "Pervasive learning games: Explorations of hybrid educational gamescapes". Simulation and Gaming 37, no. 1 (2006): 41-55. https://doi. org/10.1177/1046878105282274.

Vlahakis, Vassilios, Nikolaos Ioannidis, John Karigiannis, Manolis Tsotros, Michael Gounaris, Didier Stricker, Tim Gleue, Patrick Daehne, and Luis Almeida. "Archeoguide: an augmented reality guide for archaeological sites", IEEE Computer Graphics and Applications 22, no. 5 (2002): 52-60. 
Yang, Ruobing. "The Study and Improvement of Augmented Reality Based on Feature Matching," 2011 IEEE 2nd International Conference on Software Engineering and Service Science (ICSESS), Beijing, 15-17 July 2011, (2011): 586-589. http:// dx.doi.org/10.4236/ijids.2013.14005.

\section{Imersarea în trecut: o metodă de Realitate Augmentata pen- tru a integra patrimoniul material cu cel imaterial}

\section{Rezumat}

Actualele tehnologii informatice și digitale, cum ar fi realitatea augmentată mobilă (MAR), permit suprapunerea informațiilor digitale și reale în relație cu un subiect, într-un mod captivant și eficient și, prin urmare, pot fi utilizate pentru a stoca patrimoniul intangibil și pentru a-l studia , de asemenea, în context. Lucrarea actuală se referă la o astfel de extindere a informațiilor culturale, efectuată la situl Kallatis, ale cărui ruine, astăzi acoperite în cea mai mare parte de orașul modern, nu oferă suficiente informații despre complexitatea civilizației grecești. Implementarea aplicației MAR constă în definirea mai multor puncte de interes ale descoperirilor arheologice locale importante, care pot declanșa, pentru vizitatorii care folosesc aplicația noastră, o augmentare a sitului istoric cu imagini și videoclipuri. Prin cercetarea întreprinsă, autorii propun și demonstrează că o aplicație MAR mobilă poate constitui o metodă modernă de a oferi vizitatorilor o experiență imersivă și holistică pentru înțelegerea patrimoniului material și imaterial local.

Cuvinte-cheie: patrimoniu imaterial, realitate augmentată mobilă, imersare, puncte de interes, reconstituire.

Dragoș Gheorghiu, National University of Arts, Bucharest; Instituto Terra e Memória - Mação, Centro de Geociências da Universidade de Coimbra. email: gheorghiu_dragos@yahoo.com Livia Ștefan' Independent Researcher, email: livia.stefan@yahoo.com 